\title{
REFLEXÕES SOBRE OS MECANISMOS DE OBTENÇÃO DE TERRAS PARA REFORMA AGRÁRIA NO BRASIL
}

\section{REFLECTIONS ON LAND OBTAINING MECHANISMS FOR AGRARIAN REFORM IN BRAZIL}

\author{
Acácio Zuniga Leite \\ Universidade de Brasília, Doutorando em Desenvolvimento Sustentável no Centro de Desenvolvimento \\ Sustentável, Brasília, DF, Brasil \\ acacio_briozo@yahoo.com.br \\ Rogério Antônio Mauro \\ Instituto Federal Goiano. Doutorando em Geografia da Universidade Federal de Goiás, Goiânia, GO, \\ Brasil \\ rogerio.mauro@ifgoiano.edu.br
}

Karla Emmanuela Ribeiro Hora Universidade Federal de Goiás, Escola de Engenharia Civil e Ambiental, Pós-Graduação em Ciências Ambientais, Goiânia, GO, Brasil karla_hora@ufg.br

\section{Resumo}

Em qual contexto deu-se os mecanismos de obtenção de terras no Brasil e como explicar a redução do número de áreas desapropriadas e a ampliação dos assentamentos rurais no período 1985-2019? Esse artigo debruça-se sobre esta questão. O Brasil segue no grupo seleto de países que ainda não realizou sua Reforma Agrária. Refletir sobre as ações necessárias de Estado que garantam a desconcentração da terra e a justiça social no campo requer compreender as limitações institucionais e operacionais para a aplicação da função social da propriedade no Brasil contemporâneo. Entre 1985 e 2019 o Brasil implantou 9.367 projetos de assentamentos com capacidade de inclusão de 1.076 .939 famílias. Isso significa 78,3 milhões de hectares de terras, ou seja, 9,2\% do território nacional. Não é pouco, mas, não foi o suficiente para alterar a estrutura fundiária altamente concentrada. Para compreender isso, a metodologia empregada analisou o banco de dados da obtenção de terras na Reforma Agrária à luz das mudanças do padrão de produção na agricultura em dois períodos distintos: 1985-1999 e 2000-2019. Os resultados apontam que o fortalecimento das commodities, em fins dos anos 1990 e a expansão das áreas destinadas a elas gerou impacto nos preços de terras. Os mecanismos de obtenção de terras por meio da desapropriação não foram atualizados a fim de aplicar a função social da propriedade na sua integralidade. Assim, os instrumentos normativos sucumbem às regras que o mercado de terra imputa, dificultando, cada vez mais, uma Reforma Agrária nos moldes planejados no momento inicial da redemocratização do país.

Palavras-chave: Rural. Assentamentos rurais. Commodities. Função social da propriedade. 


\begin{abstract}
In which context did the mechanisms of land obtainment took place in Brazil? How to explain the reduction of areas by disappropriation and the expansion of rural settlements in the period 1985-2019? This article deals with both questions. Brazil follows the select group of countries that have not yet carried out an Agrarian Reform. Reflect on the necessary State actions that ensure deconcentration of land and social justice in field requires understanding the institutional and operational limitations for social function of property application in contemporary Brazil. Between 1985 and 2019, Brazil implemented 9,367 settlements projects with capacity to include 1,076,939 families. This means 78.3 million hectares of land, or $9.2 \%$ of national territory. It is not insignificant, but it was not enough to alter the highly concentrated land structure. To answer the questions, the land acquisition database of Agrarian Reform was analyzed in parallel with production pattern changes of agriculture in two distinct periods: 1985-1999 and 20002019. Results indicates that the commodites strengthment in the late 1990s and the expansion of areas allocated to them generated impact on land prices. The disappropriation mechanisms for land obtainment have not been updated to apply the social function of the property in its entirety. Thus, the normative instruments succumb to rules that the land market imputes, increasingly difficult to an Agrarian Reform as planned at the initial moment of brazilian redemocratization.
\end{abstract}

Keywords: Rural. Rural settlements. Commodities. Social function of property.

\title{
Introdução
}

A história do Brasil se confunde com a história da formação e consolidação do latifúndio e seus reflexos sob a nuvem das relações de poder criado pelo Estado moderno português de caráter patrimonialista e estamental (FAORO, 1958). Desde a divisão da colônia em capitanias hereditárias e, posteriormente, em sesmarias, a grande propriedade passou a se constituir a base da estrutura fundiária brasileira, referendada pela Lei de Terras de 1850 e os diferentes dispositivos jurídicos conseguintes que dificultaram o cumprimento da função social da propriedade desde sua insinuação na Constituição Federal de 1934, 1937 e $1946^{1}$.

\footnotetext{
${ }^{1}$ Na Constituição Federal de 1934, o artigo 113, alínea 17 menciona que: "É garantido o direito de propriedade, que não pode ser exercido contra o interesse social ou coletivo na forma que a lei determinar". A Constituição Federal de 1937, o artigo 122, alínea 14: "É garantido o direito de propriedade, cujo conteúdo e seus limites serão definidos nas leis que lhe regularem o exercício". A Constituição Federal de 1946, o artigo 147: "O uso da propriedade será condicionado ao bem-estar social. A lei poderá, com observância do disposto no art. 141, § 16, promover a justa distribuição da propriedade, com igual oportunidade para todos".
} 
Mais do que um pacto de poder, a permanência da estrutura fundiária conservadora e desigual se valeu de um aparato de Estado e Governos que não privilegiou as classes sociais mais vulneráveis. Logo, se os instrumentos normativos de acesso à terra do período colonial até a República Velha não privilegiaram os pobres e camponeses sem terra, findado o período da Ditadura Militar, em 1985, também, não se viu operacionalidade nos mecanismos destinados a fazer cumprir a função social da propriedade até então.

É notório que esse arranjo estrutural não sobreviveu de forma passiva, embora relativamente ileso. Dele se originaram inúmeras formas de lutas pela terra e por direitos dos Povos Originários, populações que foram escravizadas, agricultores(as) empobrecidos e trabalhadores(as) sem renda que se organizaram nos movimentos sociais, sindicais e populares que ao longo de séculos tentaram enfrentar o problema da concentração da terra.

O contexto da redemocratização brasileira viu o ressurgimento da luta pela terra, abafado pela perseguição e tortura ora conduzida pela Ditadura Militar. Esse cenário de efervescência política trouxe a pauta da Reforma Agrária. Em 1985 o lançamento do Plano Nacional de Reforma Agrária (PNRA), em Brasília, pelo, então, Presidente José Sarney, com meta de assentar 1,4 milhão de famílias no prazo de cinco anos visava aplicar os preceitos definidos no Estatuto da Terra (Lei no 4.504 de 30 de novembro de 1964) na implantação dos assentamentos rurais.

Todo esse debate em torno do I PNRA acabou se transformando em subsídio para a pressão social, já existente, na apresentação de propostas de mudanças constitucionais, materializadas na Carta Magna de 1988. Não obstante, viu-se reafirmada a propriedade privada como um direito fundamental, embora condicionada ao cumprimento da sua função social ${ }^{2}$. Por ela, no artigo 186, a Constituição Federal de 1988 estabeleceu que:

\footnotetext{
A função social da propriedade é cumprida quando a propriedade rural atende simultaneamente, segundo critérios e graus de exigência estabelecidos em lei, aos seguintes requisitos:

I - Aproveitamento adequado;

II - Utilização adequada dos recursos naturais e preservação do meio ambiente;

III - Observância das disposições que regulam as relações de trabalho;
}

\footnotetext{
${ }^{2}$ A Constituição Federal de 1969 mencionava, no inciso II do artigo o cumprimento da função social da propriedade, mas vinculando-o "A ordem econômica e social tem por fim realizar o desenvolvimento nacional e a justiça social [...]". Redação do inciso foi mantida no inciso XXIII do artigo $5^{\circ}$ da Constituição Federal de 1988, mas, agora, associando-a a noção de direito e garantia fundamental da propriedade.
} 
IV - Exploração que favoreça o bem-estar dos proprietários e dos trabalhadores (BRASIL, 1988).

Passados mais de trinta anos e dez governos desde a Constituição de 1988, o Brasil permaneceu na seleta lista de países que jamais ousaram romper com essa estrutura fundiária concentradora por meio de um processo massivo de redistribuição de terras ou de execução de uma Reforma Agrária efetiva. O que se viu, entre 1985 e 2019, foi a implantação de 9.367 projetos de assentamentos abrangendo 78,3 milhões de hectares de terras, ou seja, 9,2\% do território nacional, com capacidade de inclusão de 1.076.939 famílias (INCRA, 2020) ${ }^{3}$. Apesar de dados expressivos, eles não foram suficientes para superar a concentração fundiária e a condição desigual do rural brasileiro.

A categoria "assentamentos", embora tratada como generalização de processos de luta pela terra ou de mecanismo de efetuação da Reforma Agrária, abrange uma série de particularidades que, dentre outros tantos aspectos, englobam a modalidade de obtenção da terra e a tipologia do assentamento implantado (COCA, 2013; 2019).

Apesar da existência de um conjunto de trabalhos que se debruçam sobre o resultado da política agrária no período recente (FERNANDES, 2003; COSME, 2016; MATTEI, 2018), aspectos da implantação dos assentamentos e da execução da Reforma Agrária ainda permanecem pouco explorados na literatura ao se considerar, por exemplo, as formas de obtenção de terra. Para além de um balanço necessário sobre a agenda da terra, passados trinta anos da Constituição de 1988, abrir a discussão sobre os limites das ferramentas usuais de obtenção de terra é necessário para analisar o seu potencial no contexto atual brasileiro.

Isso porque o desenvolvimento do capitalismo no campo, a financeirização da agricultura e a consolidação de um mercado de terras internacional e das commodities, no final dos anos 1990, implicaram em alterações normativas que impactaram, ainda mais, os mecanismos de acesso à terra pelos pobres. Assim, estudar as formas de obtenção de terra no período pós redemocratização e seu contexto de aplicação, implica compreendê-las à luz das mudanças do padrão de produção da agricultura mundializada e seus reflexos no campo brasileiro. É sobre isso que trata a presente reflexão.

Para organizar essa discussão, o presente artigo apresenta, para além desta introdução, três seções e as considerações finais. Na primeira é exposto o contexto político e econômico

\footnotetext{
3 Neste artigo são abordados os assentamentos criados ou reconhecidos pelo Instituto Nacional de Colonização e Reforma Agrária (Incra).
} 
que influenciou a agenda agrária no período 1985-2019. Na segunda, discorre-se sobre as diferentes formas de obtenção de terras para criação de assentamentos e se debruça sobre a desapropriação como instrumento principal e mecanismo de maior legitimidade política, apesar de insuficiente, para a implantação dos assentamentos rurais. Na terceira expõe-se elementos para subsidiar as discussões futuras da Reforma Agrária que perpassam a agenda da obtenção de terras. Por fim, nas considerações finais, apontam-se questões para seguimento do debate. Destaca-se que a discussão sobre os mecanismos de aquisição de terras se insere nas contradições inerentes ao significado da propriedade e uso da terra para a agricultura.

\section{Contexto político e econômico pós Constituinte para a obtenção de terras}

A implantação ou não dos assentamentos rurais e as formas de obtenção de terras são reflexo do contexto político e econômico em que se inserem. À medida que este se altera, vêse um cenário de disputa, ampliação ou recuo nessa agenda. Tomando-se o período 19852019 é possível considerar, pelo menos, dois momentos distintos para refletir sobre essa questão: 1985-1999 e 2000-2019. No primeiro estão colocados a retomada da agenda da Reforma Agrária, o período Constituinte e a tentativa de execução do novo marco legal com o processo de redemocratização e, no segundo, assentam-se as estratégias baseadas nos preceitos do Consenso de Washington e a consolidação de uma agricultura dominada pelo grande capital e pelas commodities.

Para o primeiro período destaca-se os avanços legislativos permitidos pela Carta Magna. A Constituição Federal de 1988 reconheceu a necessidade de cumprimento da função social dos imóveis rurais e a desapropriação por interesse social. Houve avanços positivos no texto de 1988, com o marco jurídico, do ponto de vista conceitual, ao incorporar e definir três regimes fundiários: a) terras destinadas à produção agropecuária subordinadas ao princípio da função social da propriedade (artigo 186); b) criação dos regimes de terras étnicas (indígenas, artigo 231; quilombolas, ADCT, artigo 68); e o regime das unidades de conservação ambiental (artigo 225) (DELGADO, 2019). Complementarmente, restou estabelecido que a União deveria desapropriar por interesse social e destinar à Reforma Agrária os imóveis rurais que não cumprem sua função social (artigo 184).

Mas, simultaneamente, o texto constitucional criou uma série de entraves para a desapropriação dos latifúndios e a implementação de uma Reforma Agrária ampla e massiva 
(SILVA, 1989; CUNHA FILHO, 2007). Ao mesmo tempo em que se afirmava, com evidência, o cumprimento da função social da propriedade e os critérios para sua averiguação, a permanência da propriedade como um direito fundamental e a sua "prévia e justa" indenização como resposta a isso, tornava moroso e oneroso o processo de desapropriação para fins de Reforma Agrária, além da impossibilidade de desapropriação do imóvel produtivo.

O texto, também, não fez referência ao latifúndio ou a limite máximo da propriedade, além de não adotar dispositivo para a perda sumária (PEREIRA, 2015). Ademais, o rito de execução da Reforma Agrária e dos mecanismos para sua efetivação somente seriam regulamentados anos depois e muitos deles ainda encontram dificuldade de operacionalização quando se considera outros quesitos de cumprimento da função social para além da produtividade.

Há que se destacar que o limite constitucional do texto ancora-se na ação conjunta das, então recém-criadas, Frente Ampla da Agropecuária Brasileira (FAAB) e União Democrática Ruralista (UDR) contra a agenda da Reforma Agrária. A defesa da reforma agrária foi capitaneada pela Associação Brasileira de Reforma Agrária (ABRA) e pela Confederação Nacional dos Trabalhadores na Agricultura (CONTAG). A UDR compôs o núcleo ruralista conservador no Congresso Nacional e, junto com a ABAG e CNA, tiveram destaque no período pós crise cambial com a agenda do Agronegócio ${ }^{4}$.

Dar operacionalidade à carta magna e alterar o aparato estatal para sua execução segue sendo o desafio para cumprir o "espírito de cidadania" previsto na Constituição. O desmonte estatal vivido nos anos 1980 com a crise fiscal e, no início dos anos 1990, com a agenda neoliberal, geraram uma paralisia estatal na agenda agrária. O Instituto Nacional de Colonização e Reforma Agrária (INCRA), órgão responsável pela execução da Reforma Agrária, por exemplo, teve doze presidentes entre 1985-1994, entre efetivos e interinos, ficando extinto por dezessete meses. Entre 1987 e 1989, sua estrutura administrativa foi alterada seis vezes.

Na década de 1990, com o governo Itamar, houve a primeira regulamentação do rito para verificação do cumprimento da função social da propriedade rural, com a edição

\footnotetext{
${ }^{4}$ De acordo com Delgado (2006) o agronegócio é [...] uma associação do grande capital agroindustrial com a grande propriedade fundiária, sob patrocínio fiscal, financeiro e patrimonial do Estado. Essa associação persegue estrategicamente a captura do lucro multissetorial (medido pelo produto do agronegócio) e da renda fundiária capitalizada, que é ligada a um efeito riqueza, típico do arranjo fundiário nacional.
} 
da Lei Agrária (Lei no 8.629 de 25 de fevereiro de 1993) e da Lei Complementar $n^{\circ} 76$ de 6 de julho 1993, que disciplina o processo de desapropriação do imóvel que não cumprir a função social. Entretanto, sua aplicação ficou restrita à avaliação do cumprimento de produtividade por meio da avaliação dos quesitos de grau de utilização da terra (GUT) e grau de eficiência na exploração (GEE), ficando afastados aqueles relacionados às formas de trabalho, meio ambiente e bem-estar.

No final dos anos 1980 e nos anos 1990, a agricultura passava por dificuldades em consequência da crise econômica dos anos 1980 e da implantação das políticas neoliberais no Brasil, resultando nos baixos preços das terras. Inclusive, nessa época, havia muita oferta de terras pelos proprietários ao Incra. Paralelamente, a crise do mundo do trabalho em decorrência das políticas neoliberais gerava desemprego, terceirização e subemprego. A taxa de desocupação entre 1992 a 1999 variou de 6,54\% para 9,65\% (IBGE, 2020a) e forçava milhares de famílias a buscar nos acampamentos e ocupações de fazendas uma alternativa de sobrevivência, favorecendo o aumento das lutas. Nesse mesmo período, o número de acampamentos saltou de noventa e um para oitocentos e cinquenta e seis (RELATÓRIO DATALUTA BRASIL, 2019)

À medida que a luta pela terra se intensificava, via-se crescer a violência e a criminalização dos sem-terra em todo país. Entre 1985 e 1999 as mortes por conflitos totalizaram mil e trinta e oito casos (CONFLITOS NO CAMPO BRASIL, 1991; 1996; 1999). A sociedade também se sensibilizava com a luta dos sem-terra, revelada nos massacres de agricultores Sem Terra de Corumbiara, em 1995, e Eldorado dos Carajás, em 1996. Não por acaso o pico de ocupações, verificado no ano de 1999, culminou com a realização da grande Marcha à Brasília, realizada pelo Movimento dos Trabalhadores e Trabalhadoras Rurais Sem Terra (MST), que na chegada reuniu mais de cem mil pessoas na Capital Federal.

Assim, a implantação dos assentamentos não atingiu as expectativas do I PNRA e não conseguiu reconfigurar a estrutura da propriedade no Brasil no período imediatamente pós Constituinte. Ao contrário, à medida que as lutas sociais avançavam pressionando o Estado, este reagia, de um lado, implantando assentamentos de forma pontual e, de outro, criminalizando os próprios movimentos. Isso se materializaria no período 2000-2019 com novos arranjos produtivos da agricultura e novos marcos legais dificultando a implantação dos assentamentos. 
A Medida Provisória $n^{\circ} 2.183-56$ de 24 de agosto de 2001, alterou a Lei $\mathrm{n}^{\mathrm{o}}$ $8.629 / 1993$, introduzindo os seguintes parágrafos ao artigo $2^{\circ}$ desta lei,

\begin{abstract}
$\S 6^{\circ} \mathrm{O}$ imóvel rural de domínio público ou particular objeto de esbulho possessório ou invasão motivada por conflito agrário ou fundiário de caráter coletivo não será vistoriado [grifo nosso], avaliado ou desapropriado nos dois anos seguintes à sua desocupação, ou no dobro desse prazo, em caso de reincidência; e deverá ser apurada a responsabilidade civil e administrativa de quem concorra com qualquer ato omissivo ou comissivo que propicie o descumprimento dessas vedações.

$\S 7^{\circ}$ Será excluído do Programa de Reforma Agrária do Governo Federal quem, já estando beneficiado com lote em Projeto de Assentamento, ou sendo pretendente desse benefício na condição de inscrito em processo de cadastramento e seleção de candidatos ao acesso à terra, for efetivamente identificado como participante direto ou indireto em conflito fundiário [grifo nosso] que se caracterize por invasão ou esbulho de imóvel rural de domínio público ou privado em fase de processo administrativo de vistoria ou avaliação para fins de reforma agrária, ou que esteja sendo objeto de processo judicial de desapropriação em vias de imissão de posse ao ente expropriante; e bem assim quem for efetivamente identificado como participante de invasão de prédio público, de atos de ameaça, seqüestro ou manutenção de servidores públicos e outros cidadãos em cárcere privado, ou de quaisquer outros atos de violência real ou pessoal praticados em tais situações.

$\S 8^{\circ} \mathrm{A}$ entidade, a organização, a pessoa jurídica, o movimento ou a sociedade de fato que, de qualquer forma, direta ou indiretamente, auxiliar, colaborar, incentivar, incitar, induzir ou participar de invasão de imóveis rurais ou de bens públicos, ou em conflito agrário ou fundiário de caráter coletivo, não receberá, a qualquer título, recursos públicos [grifo nosso].
\end{abstract}

A proibição da desapropriação de terras ocupadas foi um duro golpe nos movimentos sociais fazendo com que refluíssem as lutas, especialmente as ocupações de terras. Se a segunda metade da década de 90 se caracterizou como um dos momentos de muitas ocupações de terras e de conquista de assentamentos, nas décadas seguintes verse-ia sua redução.

No final da década de 1990, viu-se a projeção da agricultura industrial, emulada sob o conceito de agronegócio, apresentando uma nova roupagem para a agricultura brasileira (POMPEIA, 2018). Com o déficit na balança comercial durante o Governo Fernando Henrique Cardoso, em 1995, mas, em especial, a partir da crise cambial de 1999, o setor agropecuário ganhou projeção por sua capacidade de gerar saldos positivos nas transações comerciais, diante de um cenário externo que se apresentava bastante favorável às commodities. Pela ótica do governo, este era o setor que possibilitaria o reequilíbrio das transações correntes do Brasil.

Na década de 2000, um novo cenário político se apresentava. A expectativa de um Governo popular, favorável à Reforma Agrária se transformou em estímulo às lutas 
populares, levando ao imediato aumento nas ocupações de terra. Entretanto, na proposição do II PNRA (MDA, 2003), já ficaram demonstrados os limites para uma Reforma Agrária efetiva. A meta de assentamentos de quatrocentas mil famílias por assentamentos e cento e trinta mil por meio do crédito fundiário resultou em frustração para muitos apoiadores do governo (REFORMA AGRÁRIA, 2005). O balanço final de execução dos assentamentos sequer indicava esse cumprimento de metas (MDA, 2006).

Como o número de assentamentos não acompanhou a expectativa, em especial a partir do segundo mandato de Lula, as ocupações diminuíram nos anos seguintes. Contudo, para esse fato, algumas variáveis explicativas podem ser utilizadas. Uma delas é de que o aumento no nível de emprego e renda no meio urbano tenha contribuído para a redução das ocupações e acampamentos. As taxas de desemprego nas metrópoles estiveram em patamares bastante baixos segundo padrões internacionais ainda que, de forma oculta pelo trabalho precário e pelo desalento, se situassem em patamares superiores a uma eventual situação de pleno emprego (IPEA, 2012). Adicionalmente, políticas sociais como "Minha Casa Minha Vida", "Bolsa Família" e o aumento real do salário mínimo abrangeram, parcialmente, o público potencial para a Reforma Agrária.

É importante destacar que, entre 2001 e 2015, verifica-se uma melhoria no rendimento médio mensal das pessoas com mais de dez anos entre 2001 e 2015, saltando de $\mathrm{R} \$ 366,00$ para $\mathrm{R} \$ 1.218,00$. No mesmo intervalo o número de acampamentos reduziu de duzentos e setenta e três para duzentos e cinquenta e um, conforme demonstrado no gráfico 1.

Para além das dificuldades derivadas do enfrentamento realizado entre os movimentos sociais e os governos no período anterior, a política agrária encontrou outros obstáculos oriundos da política econômica e agrícola. Assim, no início dos anos 2000, o aumento da demanda externa por commodities agrícolas e a falta de capacidade dos centros produtores em atender a demanda (SAUER, 2016), junto com o baixo preço das terras (GASQUES, BASTOS e VALDES, 2008) e a retomada no preço das commodities (FLEXOR e LEITE, 2017), criaram um cenário favorável à implementação das estratégias da concertação política do agronegócio no Brasil, como a expansão das fronteiras agrícolas e a flexibilização da legislação agrária, dentre outras pautas da agenda ruralista (DELGADO, 2012; POMPEIA, 2018). 
Gráfico 1: Brasil - Rendimento médio mensal e número de acampamentos - 2001 a 2015.

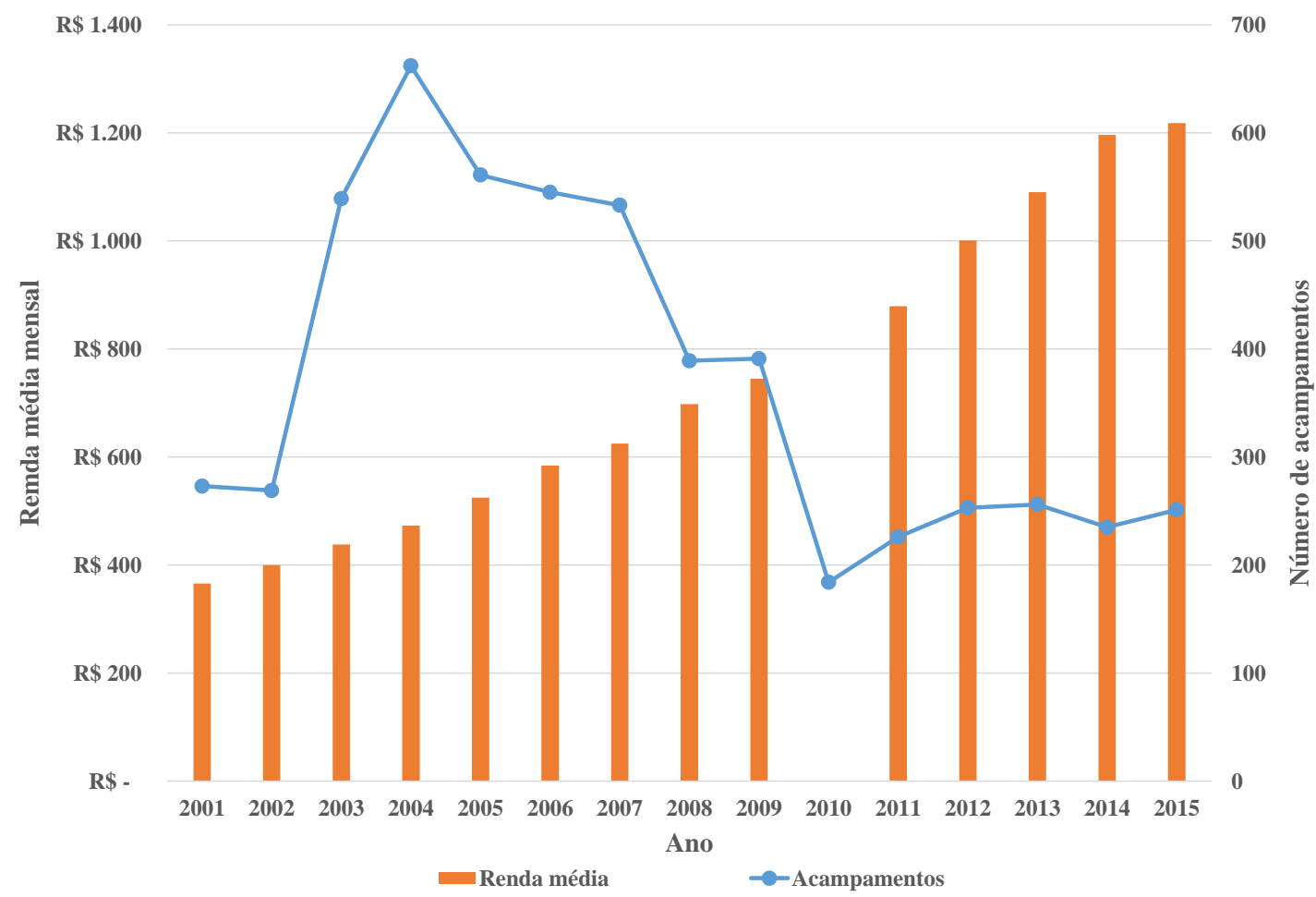

Fonte: IBGE, 2020b; RELATÓRIO DATALUTA BRASIL, 2019.

Org.: Acácio Zuniga Leite, 2020.

Nesse período destaca-se o crescimento do preço da saca de soja e da terra em áreas de produção de grãos (gráfico 2). Regionalmente, o preço da terra no período apresentado no gráfico 2 variou de 3,0 a 18,4 vezes o preço base de 2002 . O aumento do preço das terras puxado, de um lado, pelo mercado mundial de commodities e, de outro, pela política financeira e fundiária do Estado Brasileiro, implicou no aumento da renda da terra, beneficiando seus proprietários, seja pela exploração econômica do solo, ou simplesmente pelo aumento do preço destes ativos (GONÇALVES, 2005). 
Gráfico 2: Brasil - Série histórica dos preços da soja e das terras para produção de grãos, valores correntes - 2002 a 2018.

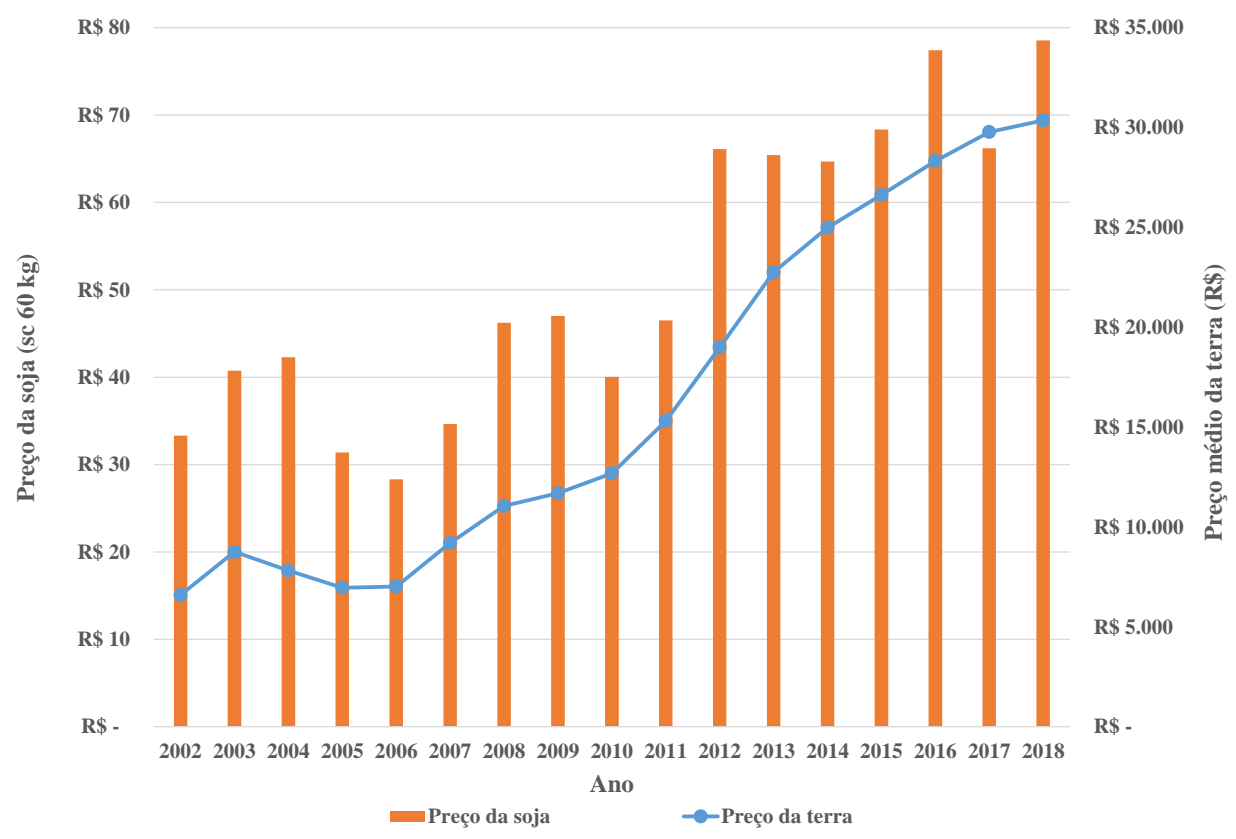

Fonte: CEPEA, 2020; INFORMA ECONOMICS FNP, 2019.

Org.: Acácio Zuniga Leite, 2020.

Esse processo implicou a incorporação de novas áreas controladas pelo modelo hegemônico do capitalismo no campo, em especial com o aumento da área plantada de soja e avanço da fronteira agrícola. Soja, milho e açúcar são as três commodities agrícolas de maior expansão no Brasil (SAUER e LEITE, 2012). No gráfico 3 são destacados o crescimento das áreas plantadas desses cultivos, ao mesmo tempo em que as áreas de arroz e feijão, produtos da cesta básica, demonstram queda.

As áreas de soja, milho e cana-de-açúcar aumentaram 101,66\% entre 1999-2018, enquanto as áreas de produção de alimentos da cesta básica, como arroz e feijão reduziram em 43,51\%. Com um pico em 2005 e ligeira queda entre 2006-2007, as áreas de soja encontram uma ascendência desde 2008. Entre 2012 e 2018 ocorreu a incorporação de grandes extensões territoriais à nova lógica produtiva. O Centro-Oeste, por exemplo, considerado celeiro do mundo no contexto das commodities brasileiras, viu crescer as áreas plantadas da cana-de-açúcar em $412 \%$, do milho 304\%, da soja $180 \%$ e do algodão em $103 \%$, entre 2000 e 2018.

Trata-se de uma nova fase do modelo de modernização agrícola, baseado na concentração fundiária, no controle oligopolizado dos mercados (antes e depois da 
porteira) e na adoção de novas tecnologias que, a partir de sua reinserção nas cadeias globais de valor, condiciona a economia interna a uma dinâmica econômica calcada na especialização regressiva do comércio.

Gráfico 3: Brasil - Série histórica de área plantada de soja, milho, feijão, arroz e canade-açúcar - 1998 a 2018.

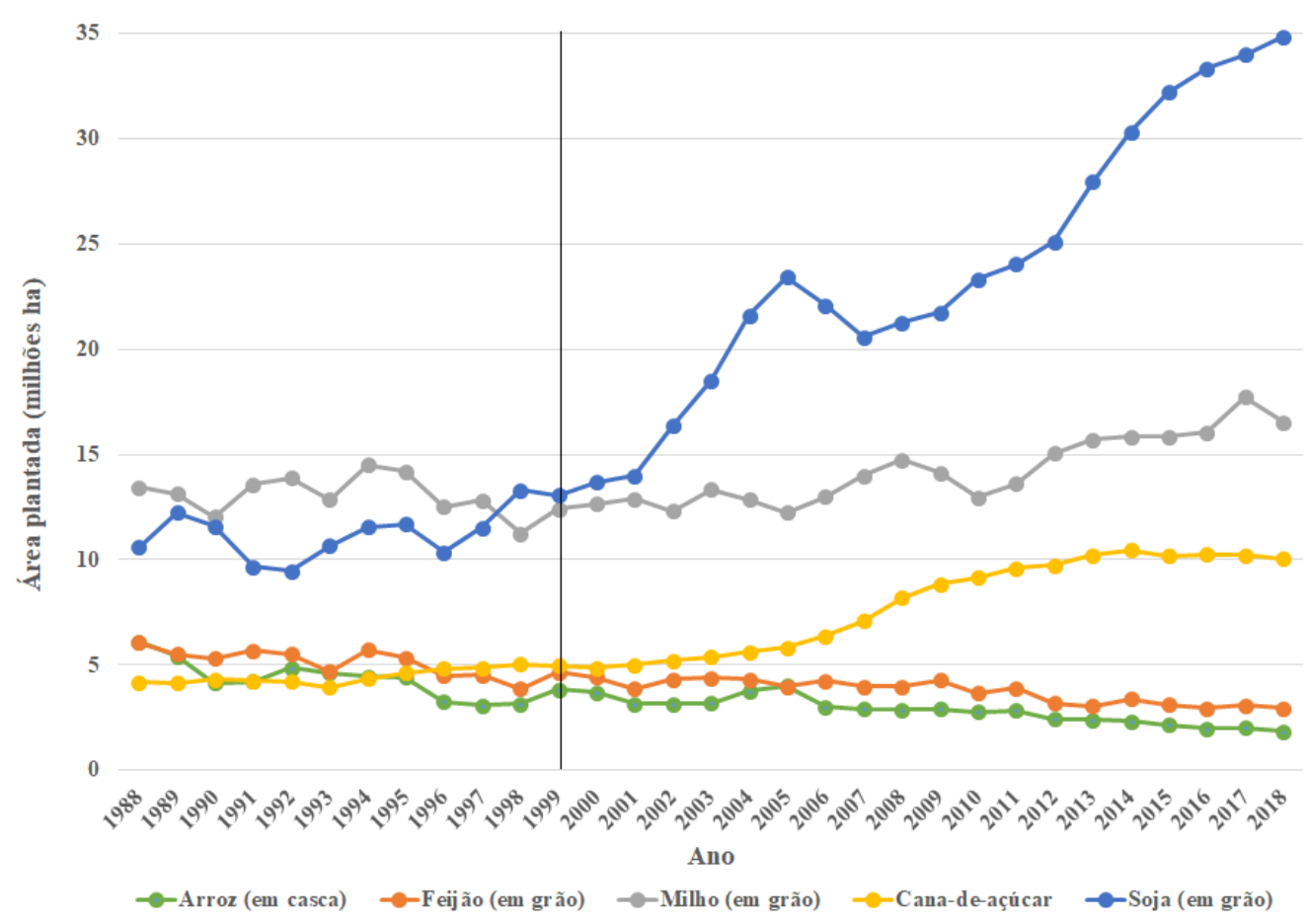

Fonte: IBGE/PAM, 2020.

Org.: Acácio Zuniga Leite, 2020.

Na prática, esse processo de aumento do preço transforma a terra na garantia real por excelência para abrir portas de acesso a mais financiamentos no mercado financeiro e quanto maiores forem esses financiamentos, maior será o aumento dos preços das terras. Além de se constituir no grande diferencial do aumento da riqueza patrimonial dos grandes proprietários de terra. Isso explica, em grande medida, a corrida em busca de terras, sobretudo, nas novas fronteiras agrícolas, como na Região do MATOPIBA ${ }^{5}$. Também ajuda a entender o interesse estrangeiro em adquirir terras no Brasil com eco no Congresso Nacional, através do Projeto de Lei (PL nº 4.059/2012), que visa permitir o

\footnotetext{
${ }^{5}$ O MATOPIBA, acrônimo formado com as iniciais dos estados do Maranhão, Tocantins, Piauí e Bahia, é uma região formada pela totalidade do estado do Tocantins e diferentes frações dos outros estados, se constitui em uma dessas áreas de grandes transformações socioeconômicas e ambientais derivadas do recente processo de implementação do modelo de produção do agronegócio.
} 
avanço na estrangeirização das terras e de grande interesse de fração da Bancada Ruralista. Acrescente-se a isso que a crise econômica mundial de $2008^{6}$, somada à continuidade da alta demanda por commodities agrícolas alimentou a corrida mundial por terras (SAUER e LEITE, 2012).

Neste contexto, diante de uma agricultura cada vez mais financeirizada, o agronegócio dispõe de dois importantes ativos negociáveis: terra e commodities, que conferem uma base real de produção e o lastro necessário e extremamente funcional para que o capital financeiro siga se reproduzindo. Isso ajuda a entender o poder real do setor ruralista e sua participação ativa em diferentes governos. Mesmo nos governos "populares", esses interesses se fizeram presentes (SVAMPA, 2013). Tal situação consolidou a posição do Brasil como pasto e lavoura mundial, ao mesmo tempo que investia no combate à fome e na erradicação da pobreza dentro de um pacto neodesenvolvimentista (BOITO JUNIOR e BERRINGER, 2014).

A dependência crescente do mercado internacional também passou a exigir do Estado o cumprimento de novas funções. Uma delas opera no sentido de assegurar as desregulamentações e flexibilizações exigidas pelo capital para entrar e sair, bem como para viabilizar o uso de suas novas tecnologias como os organismos geneticamente modificados, agrotóxicos etc., com os devidos pagamentos de royalties e patentes correspondentes etc. Outra, aponta para um Estado normatizador, regulador e fiscalizador que assegure o cumprimento de normas e padrões de qualidade exigidos pelo mercado externo, que garantam confiabilidade e em muitos casos, rastreabilidade, de produtos e processos. Embora tal ação esteja acompanhada do abandono do papel do Estado de forma mais efetiva no período pós Golpe 2016.

Novamente, é nítido e notório a atuação de um Estado dualista, que tem a força necessária para enfrentar grandes questões de interesse do grande capital e ao mesmo tempo frágil em temas como, por exemplo, da necessária atualização dos índices de produtividade agropecuária, que servem de parâmetro para aferição do cumprimento ou

\footnotetext{
${ }^{6}$ A crise de 2008, também conhecida como "crise dos subprimes" ou da "bolha imobiliária" norteamericana, foi deflagrada pela falência do tradicional banco de investimento estadunidense Lehman Brothers, fundado em 1850. Seus efeitos atingiram rapidamente a Europa ganhando o status de crise financeira internacional, que levou a quebra de grandes instituições financeiras. A crise afetou a confiança no sistema financeiro, derrubou as taxas de lucros e o crescimento econômico. Para evitar o colapso, governos das principais potências econômicas se viram obrigados a injetar grandes quantidades de dinheiro na economia e até mesmo reestatizar determinados setores econômicos.
} 
não da função social da propriedade, que seguem sendo da década de 1970, apesar de todas as transformações técnicas e ganhos de produtividade ocorridas no meio rural.

Apesar dos avanços na construção de políticas relevantes de inclusão social, assim como de outras políticas específicas para a agricultura familiar e para o público beneficiário da Reforma Agrária (FERNANDES, 2013), o pacto em questão não abriu espaço para demandas históricas, tais como, para uma Reforma Agrária ampla e massiva e o enfrentamento radical da concentração da terra. Cabe destacar que, entre 2003-2015, os governos Lula e Dilma implementaram importantes e diversificadas políticas governamentais de apoio aos assentamentos e segmentos da agricultura familiar, agora delineados pela Lei $\mathrm{n}^{\circ}$ 11.326, de 24 de julho de 2006 (GRISA; SCHNEIDER, 2015). Não obstante, tais políticas, por não se fundarem como ações de Estado e não encontrarem uma correlação de forças favoráveis na sociedade, foram gradativamente sendo desmontadas após o Golpe de 2016 (REVISTA OKARA, 2018).

Apesar das inúmeras críticas alertando para as contradições desse modelo primário exportador, que reproduz a lógica de dependência (DELGADO, 2012), a política econômica foi mantida, com o governo operando nos limites na concertação para evitar o rompimento do bloco neodesenvolvimentista de sustentação. Isso se expressava nas políticas destinadas para a agricultura familiar de um lado e no estímulo ao agronegócio de outro. Os Planos Safras da Agricultura e Agricultura Familiar dos governos LulaDilma davam sinais dessa dualidade, embora, com diferenças expressivas na oferta de recursos financeiros e de infraestrutura para os dois segmentos.

Diante de um cenário de "mercadorização" total da terra e dos recursos naturais e das limitações de uma política fundiária de Estado capaz de fazer cumprir a função social da propriedade em sua plenitude, vê-se fortalecer um regime fundiário da "terramercadoria", resultando na valorização da renda e da riqueza fundiária. Ao passo que o enfraquecimento das políticas agrárias e fundiárias, em nível federal, acaba por limitar e, em muitos casos, negar as reais possibilidades à "terra de trabalho", que se traduz na negação de direitos mais elementares de acesso a bens essenciais como terra, água e consequentemente, alimentos (DELGADO, 2019).

O caso do Código Florestal, por exemplo, é bastante emblemático, na medida em que a partir de uma série de alterações no arcabouço legislativo nacional aprofundaram-se as possibilidades de captura da renda da terra (OLIVEIRA, 2007). A alteração no Código 
Florestal (Lei $\mathrm{n}^{\mathrm{o}}$ 12.651, de 25 de maio de 2012), permitiu, dentre outras coisas, a regularização de áreas ambientalmente alteradas e surge no mesmo contexto de flexibilização das ações de destinação de terras públicas (LEITE e MOLINA, 2019).

\section{Formas de obtenção de terras para assentamentos rurais no Brasil}

Diversos países realizaram seus programas de Reforma Agrária no século XX. Stédile (2020) aglutina as experiências realizadas em clássicas, anticoloniais, radicais, populares, parciais ou moderada, de libertação nacional e socialistas, adicionando ainda as políticas de assentamento e colonização. As ferramentas utilizadas foram diversas, com destaque para a desapropriação, a tributação da terra, o financiamento subsidiado e o confisco.

No caso brasileiro, as lutas camponesas tentaram pressionar uma Reforma Agrária de Estado. Porém, apesar do Estatuto da Terra, de 1964, e do Código Florestal, de 1965, definirem os parâmetros de uso da terra, absorvidos pela Constituição de 1988, os mecanismos de obtenção de terra não se mostraram suficientes. Cabe destacar, a dificuldade do Estado Brasileiro em fazer cumprir o quesito da função social da propriedade (MITIDIERI, 2019; MARES, 2010; PINTO JÚNIOR e FARIAS, 2005). Embora haja um debate detalhado de que no preceito da função social inclui-se o quesito da produtividade e que, neste último, incluem-se as dimensões ambiental, trabalhista e de bem-estar, as formas de obtenção de terra por meio da desapropriação foram mais efetivas ao se considerar, apenas, da noção de improdutividade.

O não cumprimento pleno do artigo 186 da Constituição Federal, atestado por Mitidieri (2019) nos exemplos de obstacularização dos processos de desapropriação pelo quesito ambiental e trabalhista, imputa, também, uma dupla penalidade para a sociedade, de um lado a não realização da Reforma Agrária por meio da desapropriação para fins de implantação do assentamento rural e, de outro, uma não incorporação dos incisos II a IV na compreensão do que denominou de função social como uma característica absoluta da própria noção de propriedade.

Na prática, o que se observa considerando o exposto é que

[...] não há limites ambientais, trabalhistas e agrários ao direito de propriedade, não tão somente o primado da 'terra de negócio', assumido integralmente pelos corifeus do autodenominado agronegócio, agora alavancados também por sócios externos. Sob este pacto de poder econômico e político, terras são griladas, desmatadas e depredadas, sem qualquer consideração a sua função social e ambiental (DELGADO, 2019, p. 298). 
Assim, subordinação da execução da legislação à política estipula que a análise sobre as formas de obtenção de terras carece de contextualização de sua aplicabilidade considerando os potenciais e limitações em cada momento histórico proposto.

Essas diferenças se materializam em diversas formas, dentre elas a conformação do orçamento público. No caso do orçamento da obtenção de terras, observa-se uma tendência de queda entre 1995-2002 e uma retomada no período 2003-2005, seguida de estabilização (2006-2008) e por fim, uma nova tendência de queda em duas etapas. A primeira entre 2009 e 2015, com oscilações curtas e a um valor médio ao redor de $\mathrm{R} \$ \$ 50.000 .000,00$ e a segunda, a partir de 2016 até 2020, caracterizada por uma queda abrupta que leva praticamente ao esgotamento das possibilidades de obtenção de terras de forma onerosa. Ressalta-se que mesmo a retomada do crescimento no orçamento da obtenção de terras no período 2003-2005 (gráfico 4) não acompanhou o aumento no preço das terras.

Gráfico 4: Incra - Dotação autorizada para obtenção de terras e orçamento discricionário geral, valores correntes ${ }^{7}$ - 1995 a 2020.

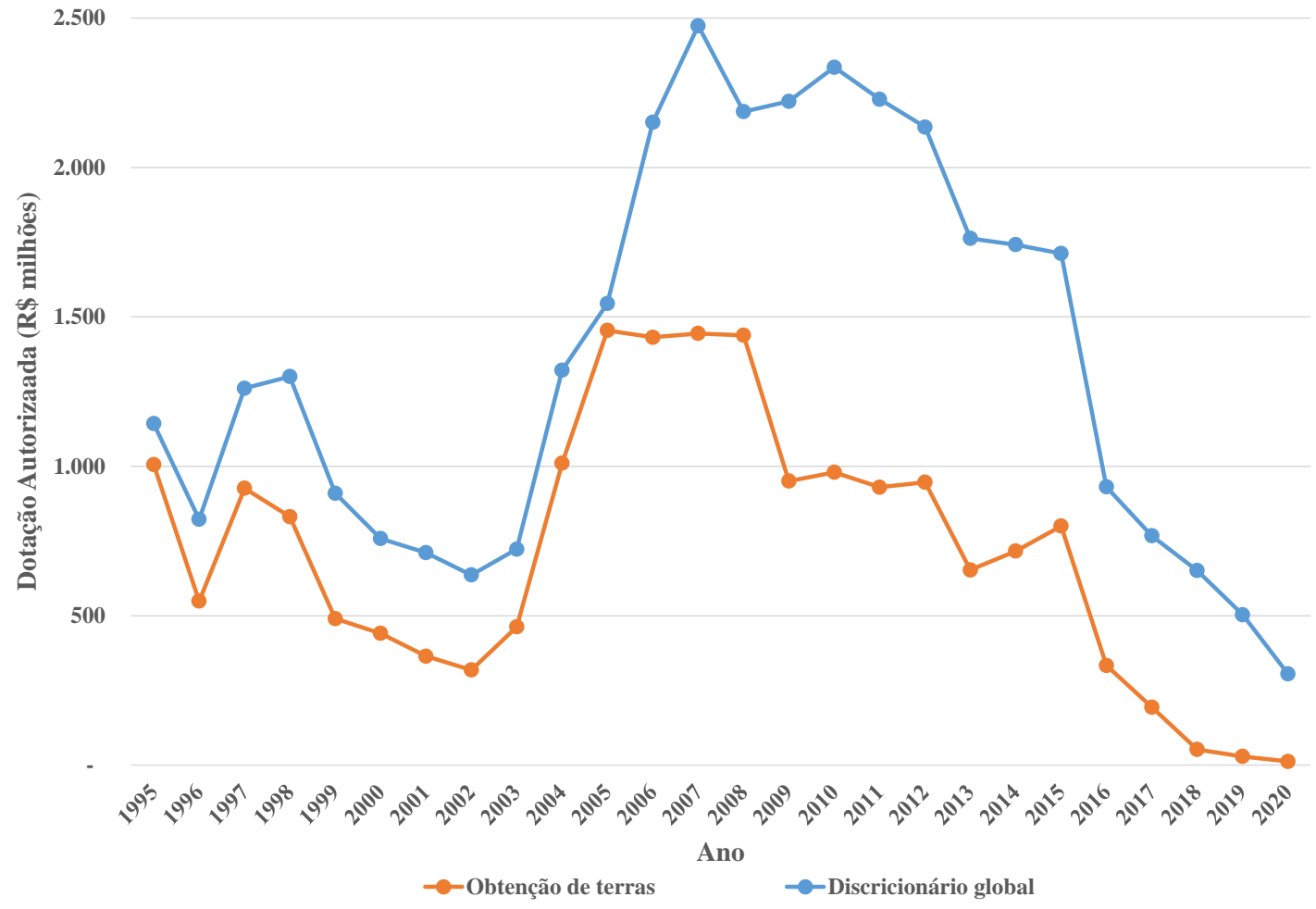

Fonte: Lei de Acesso a Informação, 2020.

Org.: Acácio Zuniga Leite, 2020.

\footnotetext{
${ }^{7}$ Só foram utilizados dados orçamentários a partir de 1995 devido a dificuldade de obter dados anteriores.
} 
De maneira geral, entre 2003-2007 o orçamento discricionário do Incra foi ampliado de $\mathrm{R} \$ 720$ milhões para $\mathrm{R}$ \$ 2,5 bilhões. Para o período seguinte, observa-se uma tendência de estabilização e posterior queda. O gráfico 4 apresenta a dotação orçamentária autorizada para obtenção de terras para criação de assentamentos e o orçamento discricionário total do Incra.

Tabela 1: Brasil - Quantitativo de assentamentos implantados, área total e capacidade de famílias, por período analisado.

\begin{tabular}{lccc}
\hline Período & $\begin{array}{c}\text { Número de } \\
\text { Assentamentos }\end{array}$ & $\begin{array}{c}\text { Número de famílias } \\
\text { (capacidade) }\end{array}$ & Área total (ha) \\
\hline $\mathbf{1 9 8 5 - 1 9 9 9}$ & 3.843 & 495.079 & 21.119 .364 \\
$\mathbf{2 0 0 0 - 2 0 1 9}$ & 5.524 & 581.860 & 57.168 .269 \\
\hline Total & 9.367 & 1.076 .939 & 78.287 .633 \\
\hline
\end{tabular}

Fonte: INCRA, 2020.

Org.: Acácio Zuniga Leite, 2020.

Tabela 02: Brasil - Forma de obtenção, quantidade de assentamentos, capacidade de famílias e área total - 1985 a $2019^{8}$.

\begin{tabular}{lccc}
\hline \multicolumn{1}{c}{ Forma } & $\begin{array}{c}\text { Quantidade de } \\
\text { assentamentos }\end{array}$ & $\begin{array}{c}\text { Capacidade de } \\
\text { famílias }\end{array}$ & Área (ha) \\
\hline Desapropriação & $5.649(\mathbf{6 0 , 3 1 \%})$ & $530.176(\mathbf{4 9 , 2 3 \% )}$ & $19.800 .725(\mathbf{2 5 , 2 9 \% )}$ \\
Reconhecimento & $1.657(\mathbf{1 7 , 6 9 \% )}$ & $198.649(\mathbf{1 8 , 4 5 \% )}$ & $35.680 .881(\mathbf{4 5 , 5 8 \% )}$ \\
Arrecadação & $709(\mathbf{7 , 5 7 \% )}$ & $155.797(\mathbf{1 4 , 4 7 \% )}$ & $14.227 .113(\mathbf{1 8 , 1 7 \%})$ \\
Compra e Venda & $549(5,86 \%)$ & $54.732(5,08 \%)$ & $1.602 .631(2,05 \%)$ \\
Cooperação com a SPU & $315(3,36 \%)$ & $72.283(6,71 \%)$ & $3.210 .900(4,10 \%)$ \\
Doação & $140(1,49 \%)$ & $15.892(1,48 \%)$ & $442.297(0,56 \%)$ \\
Transferência & $128(1,37 \%)$ & $10.622(0,99 \%)$ & $498.348(0,64 \%)$ \\
Discriminação & $56(0,60 \%)$ & $22.418(2,08 \%)$ & $2.405 .104(3,07 \%)$ \\
Confisco & $39(0,42 \%)$ & $505(0,05 \%)$ & $19.362(0,02 \%)$ \\
Adjudicação & $35(0,37 \%)$ & $1.988(0,18 \%)$ & $139.100(0,18 \%)$ \\
Reversão de Domínio & $33(0,35 \%)$ & $9.000(0,84 \%)$ & $106.790(0,14 \%)$ \\
Cessão & $14(0,15 \%)$ & $1.190(0,11 \%)$ & $11.283(0,01 \%)$ \\
Desafetação & $14(0,15 \%)$ & $902(0,08 \%)$ & $52.162(0,07 \%)$ \\
Incorporação & $8(0,09 \%)$ & $1.410(0,13 \%)$ & $63.409(0,08 \%)$ \\
Cessão Gratuita & $8(0,09 \%)$ & $661(0,06 \%)$ & $5.480(0,01 \%)$ \\
Escritura de Doação & $5(0,05 \%)$ & $293(0,03 \%)$ & $7.085(0,01 \%)$ \\
Dação & $5(0,05 \%)$ & $265(0,02 \%)$ & $5.908(0,01 \%)$ \\
Outras & $2(0,02 \%)$ & $35(<0,01 \%)$ & $2.541(<0,01 \%)$ \\
Não Informada & $1(0,01 \%)$ & $121(0,01 \%)$ & $6.516(0,01 \%)$ \\
\hline
\end{tabular}

Fonte: INCRA, 2020.

Org.: Acácio Zuniga Leite, 2020.

\footnotetext{
${ }^{8}$ Em função do limite de páginas delimitado para o artigo, a definição das modalidades e os dados regionais dos assentamentos para os diferentes períodos estão dispostos no sítio da Neagri/UnB (http://www.neagri.unb.br/index.php?option=com_content\&view=article \&id=22:informacoes-sobreassentamentos-de-reforma-agraria-no-brasil-1985-2019\&catid=2\&Itemid=376).
} 
Durante todo o período analisado (1985-2019) foram criados 9.367 projetos de assentamentos que se deram por meio de dezessete modalidades entre 1985 e 2019 (tabela 1). Esses assentamentos se concentraram nas regiões Norte e Nordeste, independente da modalidade de obtenção de terra, durante todo os dois períodos analisados. De forma geral, ao se considerar a quantidade de assentamentos e a capacidade de famílias, a desapropriação foi a modalidade principal, seguida pelo reconhecimento (tabela 2).

Em termos de área, a modalidade reconhecimento foi a maior, seguida pela desapropriação. Essa diferença é explicada pela condição de parte das áreas reconhecidas, as unidades de conservação de uso sustentável, ou seja, as Reservas de Extrativista (Resex), Florestas Nacionais (Flona) e Reservas de Desenvolvimento Sustentável (RDS). Estas áreas via de regra detém um quantitativo de área/família superior à dos assentamentos de Reforma Agrária em função dos próprios arranjos de produção sociobiodiversos existentes. Cabe evidenciar que a modalidade reconhecimento não trata da obtenção de áreas, mas do reconhecimento do público dessas áreas, com destinação prévia, como potencial beneficiário de políticas públicas afetas ao PNRA como o crédito de instalação nas diversas modalidades e o Programa Nacional de Fortalecimento da Agricultura Familiar, linha A (Pronaf A).

Há, na literatura, uma ampla discussão sobre os números da política agrária. Acusações de manipulação de dados sobre a política de criação de assentamentos permeou todo o governo Fernando Henrique Cardoso (FHC), com menor incidência nos governos Lula e Dilma. Uma síntese de diversas manifestações sobre o tema foi publicada por Scolese (2004) e ABRA (2005). Permeiam essa discussão as divergências publicizadas sobre a disparidade entre as regiões que possuíam famílias acampadas reivindicando terras e a localização em que o Estado criava os assentamentos, sobre relevância e até mesmo a legitimidade das modalidades não onerosas de obtenção de terras serem consideradas como instrumentos de Reforma Agrária por não desterritorializarem, em tese, o latifúndio (ALENTEJANO, 2004; OLIVEIRA, 2007; GIRARDI, 2009).

Olhando as formas de obtenção de terra apresentados no gráfico 5, pode-se verificar o pico das desapropriações (área e quantidade de assentamentos) em 1998. 
Gráfico 5: Brasil - Formas de obtenção de terra e capacidade de famílias, por ano, em valores absolutos - 1985 a 2019.

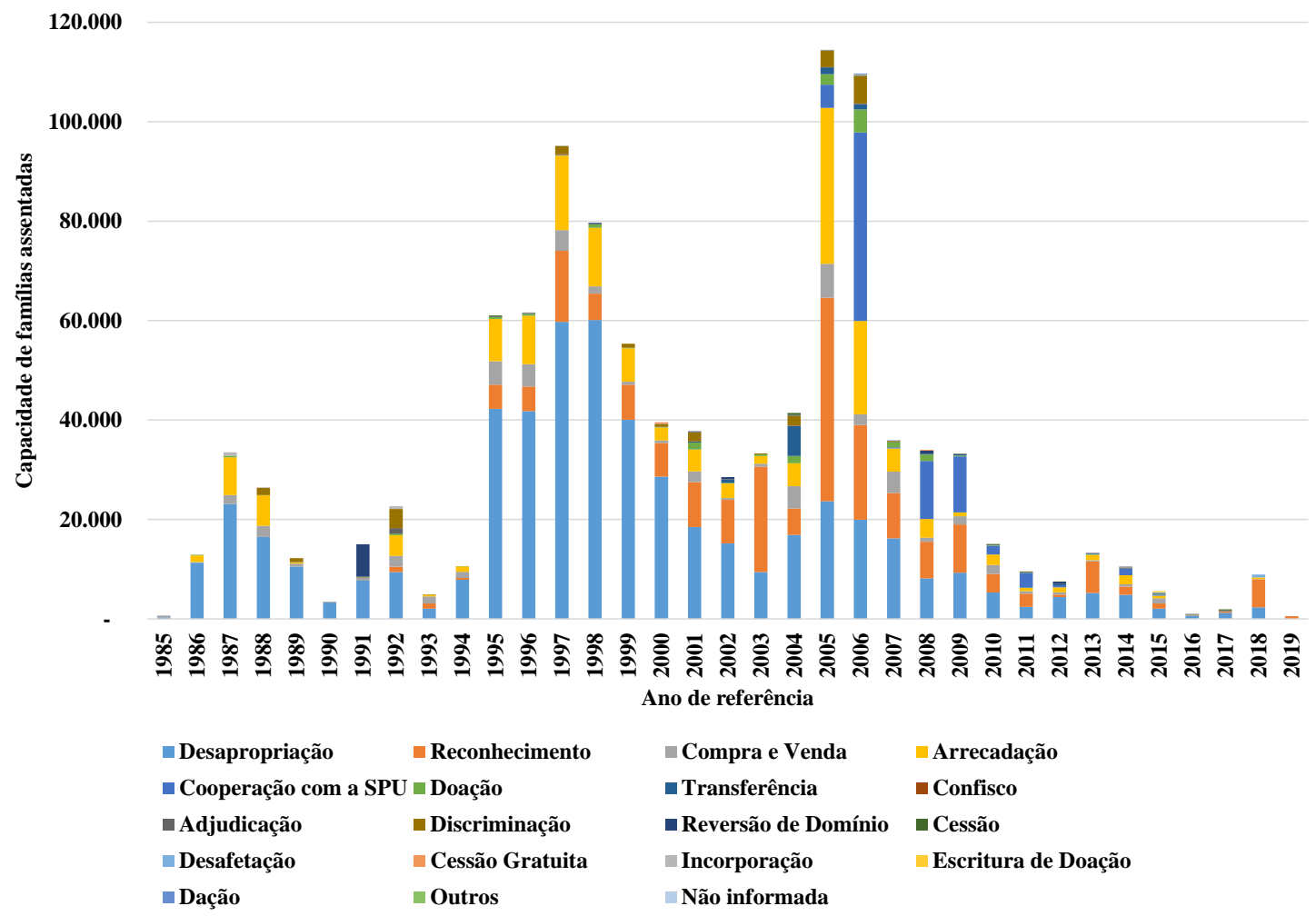

Fonte: INCRA, 2020.

Org.: Acácio Zuniga Leite, 2020.

A comparação entre os períodos 1985-1999 (que encerra com a crise cambial e a mudança na política econômica) e 2000-2019, dominado pela agenda do boom das commodities, permite destacar algumas situações que simbolizam mudanças no cenário da política fundiária.

Se, no primeiro período, a modalidade desapropriação foi responsável pela origem de $73,22 \%$ dos assentamentos, no período seguinte o resultado caiu para 51,32\%. A redução é ainda mais acentuada na capacidade de famílias $(67,86 \%$ para 33,38\%) e área $(62,04 \%$ para $11,72 \%)$. Emerge, no segundo período, o reconhecimento, modalidade que computa principalmente assentamentos estaduais, reassentamentos de barragens, territórios quilombolas e unidades de conservação de uso sustentável. Na comparação entre os períodos, o reconhecimento saltou de $11,76 \%$ para $21,81 \%$ na quantidade de assentamentos, de $7,89 \%$ para $27,43 \%$ na capacidade de famílias e de 5,69\% para 60,31\% na área. Sua alta se deu nacionalmente e também nas grandes regiões, com exceção do Sudeste. 
As modalidades "compra e venda" e "arrecadação" continuaram tendo papel relevante nos dois períodos, porém não tiveram oscilações que mereçam destaque na análise temporal. A inovação no segundo período refere-se às áreas em obtenção mediante cooperação com a Secretaria de Patrimônio da União (SPU), em especial as ilhas fluviais. Nesse período foram obtidas 315 áreas, com capacidade para 72.283 unidades produtivas e 3,2 milhões de hectares nos estados do Pará e Amazonas. Outras modalidades, de menor impacto nos resultados gerais, merecem destaque por serem inovações ou terem apresentado resultados superiores ao período anterior, como dação, desafetação, reversão de domínio, transferência e discriminação.

Gráfico 6: Brasil - Formas de obtenção de terra e capacidade de famílias, por Grande Região, em valores percentuais - 1985 a 2019.

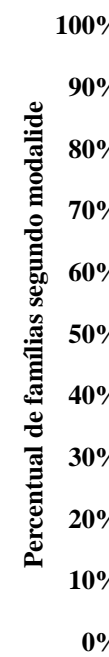

Adjudicação

Cessão Gratuita

- Dação

- Discriminação

Escritura Pública de Doação

Reconhecimento

Não informada

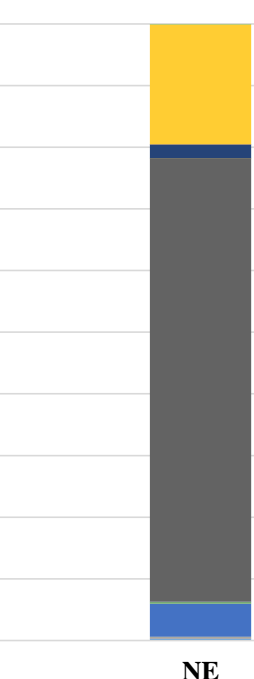

NE

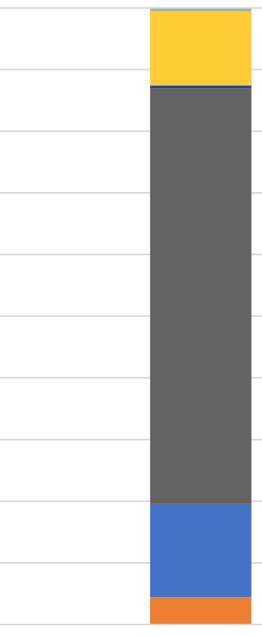

CO Grande Região

- Arrecadação

- Compra e Venda

- Desafetação

- Doação

Incorporação

- Reversão de Domínio

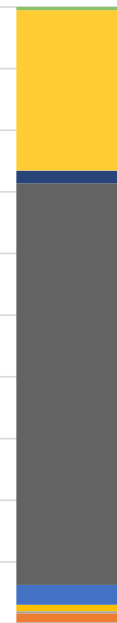

SE

— Cessão

- Confisco

- Desapropriação

- Em Obtenção - T.Coop.Tec. SPU

Outros

Transferência

Fonte: INCRA, 2020.

Org.: Acácio Zuniga Leite, 2020.

Regionalmente, as diferenças entre os períodos ganham outros matizes (gráfico 6). A quantidade de desapropriações, a área implicada e capacidade de famílias reduziram em números proporcionais em todas as regiões, com exceção do Sudeste. A compra e venda se fortaleceu nas regiões Sul, Sudeste e Centro-Oeste. A arrecadação ganhou importância nas 
regiões Norte, Nordeste, Sudeste e Sul, com pequena redução na região Centro-Oeste. Na região Norte, para além da explosão do reconhecimento e da cooperação com a SPU, a transferência, a reversão de domínio e a desafetação ganharam destaque.

Da análise dos dados frente ao contexto saltam, em especial, duas questões para debate, das quais é possível extrair informações relevantes para analisar os desafios da agenda fundiária atual. A primeira é compreender as motivações da diminuição da desapropriação e suas limitações no contexto atual. Em um cenário de política econômica que prima pelo pagamento de juros de uma dívida interna crescente e que impõe restrições orçamentárias aos gastos do governo, o orçamento destinado a aquisição de terras não foi o suficiente para execução de um programa robusto de obtenção onerosa, incluindo a desapropriação. Entretanto, para analisar tal situação, de forma aprofundada, faz-se necessário questionar a leitura de que a desapropriação somente diminuiu pela falta de orçamento e buscar aproximações sucessivas com outros elementos explicativos para a redução das possibilidades de desapropriação. Ainda que seja tímido, o avanço na compra de terras dá pistas que a onerosidade não é o fator único ou mesmo preponderante da redução das desapropriações. A segunda, imbricada à primeira, é compreender o papel das destinações de terras públicas (obtenção não onerosa) na atual conjuntura do desenvolvimento do capitalismo no campo.

Não são perguntas de respostas binárias. Em primeiro lugar, deve-se ressaltar que um dos aspectos que restringiu a avanço das desapropriações está relacionado ao aumento do preço da terra, conforme apontado na seção anterior. Mas, supondo que houvesse recursos para a obtenção de terras independentemente do preço, resta ainda necessário questionar se haveria meios de avançar de forma ampla e massiva na desapropriação de terras. Aqui a limitação estaria na compreensão de que a desapropriação para fins de Reforma Agrária está restrita à propriedade improdutiva, por força do artigo 185, II, da Constituição Federal, que impede a desapropriação de imóveis considerados produtivos. Todavia, quem cumpre a função social é a propriedade e não uma condição em si, conforme já mencionado.

Sparovek (2003) constata a existência de um passivo ambiental em parte dos imóveis desapropriados antes da criação dos assentamentos, derivado do profundo processo de degradação dos solos, matas e córregos impostos aos imóveis. Victor Oliveira (2012) também constatou, de forma detalhada, os conflitos de uso da terra em sub-bacias hidrográficas que envolviam os assentamentos de Reforma Agrária no estado de Goiás, atestando a supressão 
da vegetação em anos anteriores à implantação deles. Ou seja, aplicando-se os quesitos ambientais de uso da terra do Código Florestal (2012), muitas propriedades não cumpriam o critério mínimo de preservação das áreas ambientais.

Logo, a não aplicação de outros quesitos que definem o uso racional da propriedade para o cumprimento da função social, implica na supervalorização exclusiva do quesito produtividade. Ainda sobre o quesito produtividade, há controvérsia sobre o potencial da atualização dos índices de produtividade em classificar áreas como improdutivas disponibilizando-as para serem decretadas e destinadas para a criação de assentamentos, ainda que não se duvide da sua justeza. De fato, a modernização da agricultura e o modelo de commodities alterou as condições de produtividade nos termos mensurados em 1965. Todavia, as áreas ainda não incorporadas por esse modelo de produção encontram-se cada vez mais longe dos centros urbanos, em terras de baixa produtividade ou deslocadas das redes logísticas de transportes. Ou seja, significa fazer uma Reforma Agrária marginal aos grandes centros urbanos. Destaca-se ainda a complexidade e morosidade do processo de desapropriação, que envolve os poderes executivo e judiciário e não raras vezes tramita por anos até o desfecho.

Por fim, soma-se ao papel atual do Brasil na divisão internacional do trabalho e da produção, a vasta campanha midiática que busca apresentar que o agronegócio é a única forma de produção possível no sistema agroalimentar, de tal forma que, ele se faz presente no inconsciente coletivo como parte da construção nacional. Isso se ramifica, também, nos estudos acadêmicos além dos impactos provenientes das normas advindas dos poderes executivo e legislativo e da ação do poder judiciário.

Para analisar a segunda questão convém separar, de início, dois pontos distintos relacionados a ela: a destinação de terras públicas para a criação de assentamentos e o reconhecimento do público de áreas já destinadas para unidades de conservação como beneficiários do PNRA. Aqui, também, importa resgatar dois caminhos já trilhados para interpretação da situação. Inicialmente, o traçado por Alentejano (2004), Oliveira (2007) e Santos $(2010 ; 2011)$, analisando a política agrária nacional, e por Oliveira (2011) e Maia, Ravena e Marin (2017), analisando a criação de projetos de assentamentos agroextrativistas $\left(\mathrm{PAE}^{9}\right)$ no Pará, como exemplo. A centralidade desse primeiro caminho parte da leitura que

\footnotetext{
9 A modalidade "Projeto de Assentamento Agroextrativista", inicialmente tratada com "Projeto de Assentamento Extrativista" foi criada em 1987 (INCRA, 1987) com foco na populações extrativistas e ribeirinhas.
} 
temos uma precária política de assentamentos rurais e grande parte dos assentamentos na realidade são mera regularização fundiária. Ou seja, não se trata de obtenção de terras para assentar pessoas que não tenham acesso a esta, mas a criação de assentamentos para regularizar posseiros que já habitavam tais áreas. Nesse caso, a criação de assentamentos ambientalmente diferenciados, adaptados ao bioma amazônico, representariam, somente, um instrumento para atingir metas de regularização fundiária.

O outro caminho, iniciado por Fernandes (2010; 2013), ao tratar da escala nacional, e Coutinho (2018), para os PAE no Pará parte da compreensão de insuficiência dos resultados em termos quantitativos para a política de assentamentos, ao mesmo tempo que reconhece que o assentamento de famílias representa uma parcela importante da formação da população camponesa brasileira e contribuiu para diminuir a intensidade da queda da população rural (FERNANDES, 2013).

Marques, Del Grossi e França (2014), estudando o Censo Agropecuário 2006, identificaram que os estabelecimentos de beneficiários do PNRA ocuparam cerca de 1,9 milhão de pessoas, aproximadamente $11 \%$ do total de ocupações em estabelecimentos agropecuários no Brasil. A força de trabalho ocupada por unidade de área, para o indicador dos estabelecimentos, foi $28 \%$ superior à média nacional, com destaque para as regiões Norte e Nordeste.

Existem outras adesões, ainda que tangenciais, ao debate da pertinência e relevância da criação e do reconhecimento de assentamentos em terras públicas. Apesar de categorizar os assentamentos entre reformadores, não reformadores em áreas com ocupações e não reformadores em áreas sem ocupações, estabelecendo um grau de importância entre os assentamentos, Girardi (2009, p. 3) reconhece que "a intervenção no ordenamento da fronteira agropecuária com a criação de assentamentos [...] é sem dúvidas positivo" e que "o problema não está na criação dos assentamentos não reformadores, mas sim como eles são utilizados como estratégia para não reformar as outras regiões do país”.

Da mesma forma que foi realizado na questão anterior, busca-se questionar a leitura de que as ações de destinação de terras públicas para a criação de assentamentos (obtenção não onerosa) é simples instrumento de alcance de metas e não enfrentamento da concentração da propriedade privada. Se foi válido denunciar que os governos tentavam mobilizar a opinião pública, em especial nos anos 1990, com números de famílias assentadas sem demonstrar que havia um abismo entre a distância geográfica dos acampamentos e a criação dos 
assentamentos, resta necessário aprofundar a leitura dessa situação, agora, com algum distanciamento histórico.

Não resta dúvida de que, por um lado, os governos foram resistentes a enfrentar o latifúndio (em especial nas regiões Sul e Sudeste). Por outro lado, é importante destacar que a criação de assentamentos nas regiões Norte e Nordeste serviram como um buffer, ainda que permeável, ao avanço do latifúndio e da grilagem na região, impondo barreiras ao avanço da fronteira agrícola e, eventualmente, fazendo-a retroceder. Não significa ocultar os problemas subsequentes a essa, lembrando-se por exemplo, do caso dos projetos de assentamento agroextrativistas (PAE). É fato que as ilhas fluviais são terras da União, e isso não as livrou da incidência de falsos proprietários que subordinavam os agricultores familiares da região (MEIRELLES FILHO, 2017; ALVES, 2016).

A destinação da terra por meio da criação dos assentamentos extingue o modo de produção anterior nas áreas públicas em que os agricultores precisam remunerar um falso proprietário pela renda da terra. Em tempos de corrida por terras e expansão das fronteiras agrícolas, se a ação da destinação de terras públicas na Amazônia para a criação de assentamentos não tivesse ocorrido, provavelmente, a situação das terras públicas federais na atualidade estaria em situação ainda pior.

Experiências de assentamentos baseadas na questão ambiental também vão ao encontro das demandas dos movimentos sociais (HORA; MAURO; CALACA, 2019). Não só a forma de obtenção se coloca como pertinente, mas também, sua execução permite a implantação de projetos diferenciados. Políticas públicas iniciadas, tais como a Garantia de Preços Mínimos para os Produtos da Sociobiodiversidade (PGPM-Bio) e a assistência técnica e extensão rural específica para unidades de conservação de uso sustentável e projetos de assentamento agroextrativistas, são marcos importantes - ainda que insuficientes - para estimular a permanência no rural e combater a exclusão (AMIN, 2012) e a expulsão (SASSEN, 2006), além de reconhecer a importância dessas novas modalidades de assentamento. Afinal, qual seria o eventual destino dos milhões de agricultores familiares numa sociedade em franca desindustrialização a continuar o avanço do agronegócio?

Embora Girardi (2009, p. 03) argumente que "a criação de unidades de conservação de uso sustentável, reconhecidas como assentamentos rurais, não desconcentra a terra. Essas áreas não fazem parte da estrutura fundiária e geralmente são criadas em terras públicas, o que não implica em desapropriação de terras”, Saretta (2017) aponta a necessidade de R\$ 20 
bilhões para custear o passivo federal de desapropriação de áreas particulares em unidades de conservação.

Para além da disputa permanente em relação a destinação das terras públicas, há também um rol de tentativas de desafetação das terras já destinadas. Isso se visualiza na forma de ação direta, como no "dia do fogo", em 10 de agosto de 2019, que comprometeu diferentes unidades de conservação, e no campo legislativo com a edição das Medidas Provisórias na tentativa de recategorização e redução de áreas de proteção ambiental (LEITE, CASTRO e SAUER, 2018; LEITE e MOLINA, 2019). O mesmo ocorre com assentamentos já criados por meio da ameaça de desistência da desapropriação de áreas decretadas e não homologação de famílias (LEITE, 2019; SAUER, LEITE e TUBINO, 2020) e demarcação de terras étnicas (SAUER, LEITE e TUBINO, 2020).

\section{Qual agenda é possível considerar para a obtenção de terras?}

Retomar a construção de uma agenda de destinação de terras de forma que desconcentre a sua posse e uso se coloca como agenda desafiadora para o campo agrarista. Isso porque o desmonte e a paralisação das instituições públicas pós Golpe de 2016 esvaziou, também, o debate da terra no projeto de nação.

A destinação de uma área para a Reforma Agrária significa alterar a estrutura fundiária existente moldada na histórica concentração da terra no país. Isto é notadamente nítido na inversão da condição de propriedade pelo rito sumário constitucional.

Entretanto, a demora no rito administrativo no Poder Executivo, que envolve a adoção do mecanismos operativos para a realização de estudos preliminares até a decretação das áreas para assentamentos, aliado à demora do Poder Judiciário em emitir o Incra na posse dos imóveis, a previsão de juros compensatórios (muito superiores a qualquer aplicação atual de renda fixa no Brasil ainda que tenham havido mudanças na edição da Lei nº 13.465/2017) e as frequentes decisões judiciais para complementação dos valores precificados inicialmente pelo Incra, tornam o processo de obtenção de terras por desapropriação cada vez mais ineficaz (LEITE, 2019).

Ao se verificar a remuneração compensatória prevista na legislação, em valores e condições de pagamento que, muitas vezes, o mercado não está disposto a prover, esta permite que outras terras possam ser apropriadas pelo antigo proprietário. Apesar da sua importância, a medida foi insuficiente para sustentar um processo amplo de criação de 
assentamentos no período. Quiçá se apresentou como mecanismo sancionário do ponto de vista econômico.

Vê-se, assim, que as modalidades de obtenção de terras por meio do "reconhecimento" de novas áreas e da cooperação com a SPU apresentam-se como uma estratégia mais efetiva no período recente. Por elas, ganham destaque outras formas de luta que, também, se apresentam como legítimas ao se combater o latifúndio e podem ter três significados síntese: (i) afirmar que a luta de Irmã Dorothy para a destinação de uma gleba pública de terra para a criação do Projeto Desenvolvimento Sustentável Esperança em Anapú, no Pará, foi importante, pois se trata de uma área obtida por arrecadação; (ii) as lutas empreendidas por povos e comunidades tradicionais para demarcação das suas terras em áreas públicas, como as empreendidas pelas comunidades de Fundos de Pasto na Bahia e pelos ribeirinhos que manejam açaizais na Ilha do Marajó no Pará (onde muitas vezes estavam submetidos aos sistemas de meia e terça), são relevantes e preservam modos de vida da agricultura familiar e camponesa e; (iii) as políticas de desenvolvimento ligadas a política de criação e reconhecimento de assentamentos de Reforma Agrária, podem contribuir para resultados favoráveis no campo econômico e produtivo e para alavancar a defesa da agricultura familiar como elemento relevante em um projeto de nação.

Essa agenda precisa ser tomada com atenção, assim como, o atributo da desapropriação. Não significa substituir um pelo outro, mas ampliar o escopo de possibilidades de enfrentamento ao latifúndio no terreno tanto da normatividade quanto da operacionalidade do Estado. Estado esse que segue atrelado aos resquícios patrimonialistas e à lógica da subalternidade da produção da agricultura familiar e camponesa.

Como nos lembra Amin (2012), ainda que, nesta crise, há muitos monstros que aparecem nas sombras, é preciso gestar o novo. Urge superar os entraves apontados anteriormente para avançar nessa agenda. Para isso, quatro possibilidades são apontadas, para além da destinação de terras públicas.

A primeira é enfrentar o tema da adjudicação e obter terras dos grandes devedores da União, que somavam 1,2 trilhões em dívidas federais em 2016 e possuem áreas suficientes para assentar mais de 200 mil famílias (OXFAM, 2016).

A segunda é utilizar da instituição do interesse social para a decretação de áreas desvinculada da atual compreensão da produtividade (Lei ${ }^{\circ} 4.132$ de 10 de setembro de 1962), em especial nas áreas rurais limítrofes com as cidades, e destiná-las para a geração de 
ocupações rurais e fortalecimento das cadeias curtas de abastecimento. Esse mecanismo também pode se dar à luz do Estatuto das Cidades (Lei no 10.257 de 10 de julho de 2001) no estabelecimento do Plano Diretor do Município ou do Estatuto da Metrópole (Lei no 13.089 de 12 de janeiro de 2015) ao se indicar áreas de uso especial ou de interesse social.

A terceira é enfrentar a tributação da terra de maneira adequada. Embora existam divergências sobre o potencial de arrecadação do Imposto Territorial Rural (ITR) não restam dúvidas que há evasão e inadimplência robustas, o que não parece ser razoável em tempos de sensoriamento remoto avançado (SOUZA, 2004; FARIAS, SILVA e LEITE, 2018; INSTITUTO ESCOLHAS, 2019). Para além do efeito fiscal, a aplicação rigorosa do ITR pode ter valorosos efeitos extrafiscais.

Por fim, a última proposta está vinculada a necessidade e oportunidade de dialogar com as duas contradições do agronegócio que tiveram maior capacidade de aglutinação de setores no último período: as questões alimentar e ambiental. Daí deriva a possibilidade de avançar na regulamentação do uso da terra, impondo uma tributação do uso inadequado (LEITE et al. 2018) e o respectivo financiamento de ações que atendam a conservação ambiental e a produção de alimentos saudáveis. Por esse mecanismo, aproxima-se da efetividade do quesito ambiental no cumprimento da função social.

Experiências que podem ser alargadas com o estatuto da questão ambiental, tais como os Projetos de Desenvolvimento Sustentável, Projetos de Assentamentos Agroflorestais e os Projetos de Assentamentos Agroextrativistas ganham relevância numa agenda de promoção da agroecologia, da implantação de territórios livres de transgênicos e em outras relações de produção-consumo em áreas metropolitanas.

Alguns desses atributos podem ser lançados no delineamento dessas áreas, tais como sua reclassificação nos zoneamentos regionais, se constituem em brechas para a luta da Reforma Agrária por meio da implantação dos assentamentos.

\section{Considerações finais}

Realizar um balanço das experiências de criação de assentamentos no período democrático por meio dos mecanismos de obtenção de terra implica em compreender os limites e desafios operacionais em executar uma Reforma Agrária no Estado capitalista contemporâneo. Se, de um lado, as lutas sociais impulsionaram e alavancaram uma agenda da Reforma Agrária nos governos pós redemocratização, por outro lado, viu-se uma limitação 
dos instrumentos normativos e operacionais no atendimento dessa agenda popular. Esse aspecto encontra obstáculos tanto na natureza do desenvolvimento do capitalismo no campo, de caráter rentista e financeiro, quanto nos percalços do papel do Estado que segue atuando no sentido de privilegiar as camadas abastadas da sociedade em detrimento da execução da Reforma Agrária. Condição esta, notoriamente verificada com o fortalecimento das commodities no período 2000-2019.

O rito imposto ao processo de desapropriação, subordinado ao poder judiciário, revelou-se, com o passar dos anos, lento, limitado, oneroso e pouco sancionário. Resta necessário compreender que as ferramentas usuais, na atual fase de acumulação da economia do agronegócio, não são capazes de apresentar respostas que fujam do pontual. Os resultados aqui encontrados abrem a necessidade de pesquisas complementares, não só para o campo da reforma agrária, mas também para a agenda da criação de unidades de conservação e outras agendas relacionadas com a pauta fundiária. Como consequência, urge alimentar o quanto antes uma ampla discussão sobre as formas de obtenção da terra para um próximo período progressista sob pena de que, quando ele chegar, as ferramentas colocadas sigam sendo insuficientes.

\section{Agradecimentos}

Agradecemos Sérgio Sauer e Junior Fideles pela leitura crítica de um primeiro esboço de roteiro do manuscrito.

\section{REFERÊNCIAS}

ALENTEJANO, Paulo R. R. A política de assentamentos rurais do governo FHC e os desafios da reforma agrária no Brasil do século XXI. Agrária, n. 1, p. 2-15, 2004.

\section{ALVES, Fábio (org.). A função socioambiental do patrimônio da União na} Amazônia. Brasília: IPEA, 2016.

AMIN, Samir. Contemporary Imperialism and the Agrarian Question. Agrarian South: Journal of Political Economy, Nova Delhi, v. 1, n. 1, p. 11-26, 2012.

BOITO, Armando; BERRINGER, Tatiana. Social classes, neodevelopmentalism, and Brazilian foreign policy under Presidents Lula and Dilma. Latin American

Perspectives, Riverside, v. 41, n. 5, p. 94-109, ago. 2014.

BRASIL. Constituição da República Federativa do Brasil de 1988. Brasília:

Presidência da República, [2020]. Disponível em: 
http://www.planalto.gov.br/ccivil_03/Constituicao/Constituiçao.htm. Acesso em: 20 jun. 2020.

CEPEA. Indicador da soja CEPEA/ESALQ - Paraná. [Piracicaba]: CEPEA, [2020]. Disponível em: https://www.cepea.esalq.usp.br/br/consultas-ao-banco-de-dados-dosite.aspx. Acesso em: 04 jun 2020.

COCA, Estevan L. F. Debatendo o conceito de reforma agrária: considerações sobre os tipos de assentamentos rurais no Brasil. Campo-Território: Revista de Geografia Agrária, Uberlândia, v. 8, n. 16, ago. 2013.

COCA, Estevan L. F. Políticas de obtenção dos territórios dos assentamentos rurais em Minas Gerais. In: SIMPÓSIO INTERNACIONAL DE GEOGRAFIA AGRÁRIA, 9, 2019. Recife. Anais [...] Recife: UFPE, 2019. Disponível em http://www.singa19.com.br/resources/anais/8/singa2019/1569962852_ARQUIVO_d9e3 a8e36b4e4a799858a5e0e2d016bb.pdf $+\& c d=1 \& \mathrm{hl}=$ pt-BR\&ct=clnk\&gl=br. Acesso em 20 nov. 2019.

CONFLITOS NO CAMPO BRASIL. Goiânia: CPT Nacional, 1991-2020. ISSN 1676$661 X$.

COSME, Claudemir M. Reforma agrária no Brasil do século XXI: qual reforma agrária? Boletim DATALUTA, Presidente Prudente, n. 106, p. 2-25, out. 2016. Disponível em http://docs.fct.unesp.br/nera/artigodomes/10artigodomes_2016.pdf. Acesso em 24 jun. 2020.

COUTINHO, Marcius V. Terras de identidade e terras de conflito: movimento social ribeirinho e regularização fundiária nas ilhas e várzeas de Abaetetuba - PA. Estudos Sociedade e Agricultura, Rio de Janeiro, v. 26, n. 1, p. 33-64, fev/mai. 2018.

CUNHA FILHO, Sergio de B. Constituição de 1988 e a diminuição do poder estatal de desapropriar os imóveis rurais para fins de reforma agrária. 2007. (Mestrado em Direito). Departamento de Direito, Pontifícia Universidade Católica do Rio de Janeiro, Rio de Janeiro, 2007.

DELGADO, Guilherme C. O Significado do Agronegócio no Brasil. In: Jornal da Unesp, São Paulo, ano 20, n. 211, mai. 2006, suplemento. Disponível em: http://www.unesp.br/aci/jornal/211/suplec.php. Acesso em: 10 jun. 2020.

DELGADO, Guilherme $\mathrm{C}$. Do capital financeiro na agricultura à economia do agronegócio: mudanças cíclicas em meio século (1965-2012). Porto Alegre: Editora da UFRGS, 2012.

DELGADO, Guilherme C. Terra, trabalho e dinheiro: regulação e desregulação em três décadas da Constituição Federal de 1988. São Paulo: Edições Loyola, 2019.

FAORO, Raimundo. Os Donos do Poder: formação do patronato político brasileiro. Porto Alegre: Editora Globo, 1958. 
FARIAS, Fátima M. G. B.; SILVA, Raimundo P.; LEITE, Acácio Z. Imposto Sobre a Propriedade Territorial Rural (ITR). In: FAGNANI, Eduardo (org.). A Reforma Tributária Necessária: diagnóstico e premissas. Brasília: ANFIP; FENAFISCO; São Paulo: Plataforma Política Social, 2018, p. 394-410.

FERNANDES, Bernardo M. Reforma agrária no governo Lula: a esperança. [S. 1.: s. n.], set. 2003. Disponível em:

http://www2.fct.unesp.br/nera/publicacoes/LULA_RA.pdf Acesso em: 26 jun. 2020.

FERNANDES, Bernardo M. Reconceitualizando a reforma agrária. Boletim

DATALUTA, Presidente Prudente, n. 31, p. 2-4, jul. 2010. Disponível em: http://www2.fct.unesp.br/nera/boletimdataluta/boletim_dataluta_07_2010.pdf. Acesso em: 20 jun. 2020.

FERNANDES, Bernardo M. A reforma agrária que o governo Lula fez e a que pode ser feita. In: SADER, Emir (org.). 10 anos de governos pós-neoliberais no Brasil. São Paulo: Boitempo; Rio de Janeiro: FLACSO, 2013, p. 191-205.

FLEXOR, George; LEITE, Sérgio P. Mercado de terra, commodities boom e land grabbing no Brasil. In: MALUF, Renato S.; FLEXOR, George (org.). Questões agrárias, agrícolas e rurais: conjunturas e políticas públicas. Rio de Janeiro: E-Papers, 2017, p. 20-31.

INFORMA ECONOMICS FNP. Análise do mercado de terras. São Paulo: IFNP, 2019.

GASQUES, José G.; BASTOS, Eliana T.; VALDES, Constanza. Preços da terra no Brasil. In: CONGRESSO DA SOBER, 46, 2008. Anais [...] Rio Branco: SOBER, 2008. CD-ROM.

GIRARDI, Eduardo P. Quanto reformadora é a política de assentamentos rurais? Presidente Prudente, Núcleo de Estudos, Pesquisas e Projetos de Reforma Agrária, mai. 2009. Disponível em: http://docs.fct.unesp.br/nera/artigodomes/5artigodomes_2009.pdf. Acesso em: 24 jun 2020.

GONÇALVES, José S. Agricultura sob a égide do capital financeiro: passo rumo ao aprofundamento do desenvolvimento dos agronegócios. Informações Econômicas, São Paulo, v. 35, n. 4, p. 7-36, 2005.

GRISA, Catia; SCHNEIDER, Sergio (org.). Políticas Públicas de desenvolvimento rural no Brasil. Porto Alegre: Editora da UFRGS, 2015.

HORA, Karla E.; MAURO, Rogério A.; CALACA, Antonio. Desafios para o parcelamento dos assentamentos de reforma agrária sob a perspectiva ambiental a partir da experiência do MST em Goiás. Revista NERA, Presidente Prudente, v. 22, n. 49, p. 140-167, mai/ago. 2019. 
IBGE. Pesquisa Agrícola Municipal: Tabela 5457 - Área plantada ou destinada à colheita, área colhida, quantidade produzida, rendimento médio e valor da produção das lavouras temporárias e permanentes. [Rio de Janeiro: IBGE, 2020]. Disponível em: https://sidra.ibge.gov.br/tabela/5457. Acesso em: 10 jun 2020.

IBGE. Séries Históricas e Estatísticas: Taxa de desocupação - população de 10 anos ou mais de idade. [Rio de Janeiro: IBGE, 2020]. Disponível em:

https://seriesestatisticas.ibge.gov.br/lista_tema.aspx?op=0\&no=7. Acesso em: 20 jun. 2020.

IBGE. Séries Históricas e Estatísticas: Rendimento médio mensal das pessoas de 10 anos ou mais de idade (R\$). [Rio de Janeiro: IBGE, 2020]. Disponível em: https://seriesestatisticas.ibge.gov.br/series.aspx $?$ no $=7 \& o p=2 \& v$ codigo $=P D 345 \& \mathrm{t}=$ rendi mento-medio-mensal-pessoas-10-anos. Acesso em: 20 jun. 2020

INCRA. Portaria INCRA/P/Nº 627. [Brasília: INCRA], 1987.

INCRA. Relatório SIPRA 227. [Brasília: INCRA], 2020. Extração em 03 de janeiro de 2020.

INSTITUTO ESCOLHAS. Imposto Territorial Rural: justiça tributária e incentivos ambientais. São Paulo: Instituto Escolhas, abr. 2019.

IPEA. Considerações sobre o pleno emprego no Brasil: Comunicados do IPEA n. 135. Brasília: IPEA, 2012.

LEITE, Acácio Z. A paralisação da criação de assentamentos de reforma agrária e da homologação de famílias. Boletim DATALUTA, Presidente Prudente, n. 136, p. 2-7, abr. 2019. Disponível em:

http://www2.fct.unesp.br/nera/boletimdataluta/boletim_dataluta_4_2019.pdf. Acesso em: 20 jun. 2020.

LEITE, Acácio Z.; CARDOSO, Alessandra; DAVID, Grazielle; Mendonça, Kamila V. de; SIQUEIRA, Marcelo L. Reforma tributária ambiental: perspectivas para o sistema tributário nacional. In: FAGNANI, Eduardo (org.). A Reforma Tributária Necessária: diagnóstico e premissas. Brasília: ANFIP; FENAFISCO; São Paulo: Plataforma Política Social, 2018, p. 394-410.

LEITE, Acácio Z.; MOLINA, Caroline. Instrumentos de la agenda neoliberal del gobierno Temer desde las perspectivas agraria, ambiental y minera. In: CONGRESO INTERNACIONAL ALAS, 32, 2019. Anais [...], Lima: Alas, 2019.

LEITE, Acácio Z.; CASTRO, Luís F. P.; SAUER, Sérgio. A questão agrária no momento político brasileiro: liberalização e mercantilização da terra no estado mínimo de Temer. Revista OKARA: Geografia em debate, João Pessoa, v.12, n.2, p. 247-274, mai/ago. 2018. 
MAIA, Rosane O. M.; RAVENA, Nirvia; MARIN, Rosa E. A. Reforma agrária do governo Lula: a regularização fundiária e os assentamentos nas ilhas do Pará. Revista NERA, Presidente Prudente, ano 20, n. 35, p. 153-173, jan/abr. 2017.

MARÉS, Carlos F. Função Social da Propriedade. In: SONDA, Claúdia;

TRAUCZYNSKI, Silvia C. (org.). Reforma Agrária e Meio Ambiente: Teoria e prática no Estado do Paraná. Curitiba: ITCG, 2010. Disponível em:

http://www.itcg.pr.gov.br/modules/conteudo/conteudo.php?conteudo=79. Acesso em: 20 jun 2020.

MARQUES, Vicente P. M. de Azevedo; DEL GROSSI, Mauro E.; FRANÇA, Caio G. de. A reforma agrária no Censo Agropecuário 2006. In: SCHNEIDER, Sergio; FERREIRA, Brancolina; ALVES, Fábio. Aspectos multidimensionais da agricultura brasileira: diferentes visões do Censo Agropecuário 2006. Brasília: IPEA, 2014, p. 215-240.

MATTEI, Lauro. A política agrária e os retrocessos do governo Temer. Revista OKARA: Geografia em debate, João Pessoa, v. 12, n. 2, p. 293-307, mai/ago. 2018.

MDA. Desenvolvimento agrário como estratégia: balanço MDA 2003/2006. Brasília: MDA, 2006.

MDA. II Plano Nacional de Reforma Agrária: paz, produção e qualidade de vida no meio rural. [Brasília]: MDA, [nov. 2003].

MEIRELLES FILHO, João C. de S. Arroz no Marajó: a impunidade do agronegócio. Inclusão Social, Brasília, v. 7, n. 2, p. 86-96, jan/jun. 2014.

MITIDIERI, Leandro. Reforma Agrária como Objetivo Fundamental Constitucional de Redução de Desigualdades Sociais. In: A reforma agrária e o sistema de justiça. Brasília: MPF, 2019, p. 150-168. Disponível em: http://www.mpf.mp.br/pfdc/midiateca/nossas-publicacoes/a-reforma-agraria-e-osistema-de-justica-2019 Acesso em: 18 jun. 2020.

OLIVEIRA, Ariovaldo U. de. Modo de produção capitalista, agricultura e reforma agrária. 1.ed. São Paulo: FFLCH/USP, 2007.

OLIVEIRA, Maria R. A política de regularização fundiária e reforma agrária: o PAE nas ilhas do Pará. 2011. (Mestrado em Desenvolvimento Sustentável). Núcleo de Altos Estudos Amazônicos, Universidade Federal do Pará, Belém, 2011.

OLIVEIRA, Victor T. de. Conflito de usos em áreas de preservação permanente de assentamentos rurais e demais áreas em bacias hidrográficas de Goiás. 2013. (Mestrado em Engenharia do Meio Ambiente). Escola de Engenharia Civil, Universidade Federal de Goiás, Goiânia, 2013.

OXFAM. Terrenos da desigualdade: Terra, agricultura e desigualdades no Brasil rural. [S. 1]: OXFAM, nov. 2016. Disponível em: https://oxfam.org.br/wp- 
content/uploads/2019/08/relatorio-terrenos_desigualdade-brasil.pdf. Acesso em: 26 jun. 2020 .

PEREIRA, João M. M. Estado e mercado na reforma agrária brasileira (1988-

2002). Revista Estudos Históricos, Rio de Janeiro, v. 28, n. 56, p. 385-404, dez. 2015.

PINTO JÚNIOR, Joaquim M.; FARIAS, Valdez A. Função social da propriedade: dimensões ambiental e trabalhista. Brasília: Núcleo de Estudos Agrários e Desenvolvimento Rural, 2005. Disponível em: http://www.reformaagrariaemdados.org.br/sites/default/files/pageflip-4204232-741451t_Funo_Social_da_Propri-985138.pdf. Acesso em: 21 jun. 2020

POMPEIA, Caio. Formação política do agronegócio. 2018. (Doutorado em Antropologia Social). Instituto de Filosofia e Ciências Humanas, Universidade de Campinas, Campinas, 2018.

REFORMA AGRÁRIA. São Paulo: ABRA, v. 32, n. 1, 2005. ISSN 0102-1184.

RELATÓRIO DATALUTA BRASIL. Presidente Prudente: NERA, 2019. ISSN 25954296. Disponível em: http://www2.fct.unesp.br/nera/relatoriosbr.php. Acesso em: 20 jun 2020.

REVISTA OKARA: Geografia em debate. Dossiê Michel Temer e a Questão Agrária. João Pessoa, DGEOC/CCEN/UFPB, v. 12, n. 2, mai/ago. 2018. ISSN 1982-3878. Disponível em: https://periodicos.ufpb.br/ojs2/index.php/okara/issue/view/2129. Acesso em: 30 jun 2020 .

SANTOS, Rafael de O. C. dos. O que teve de reforma agrária no Governo Lula? Campo-Território: Revista de Geografia Agrária, Uberlândia, v. 6, n. 12, p. 63-78, ago. 2011.

SANTOS, Rafael de O. C. dos. Regularização fundiária como política de reforma agrária? Boletim DATALUTA, Presidente Prudente, n. 33, p. 2-4, set. 2010.

Disponível em:

http://www2.fct.unesp.br/nera/boletimdataluta/boletim_dataluta_09_2010.pdf. Acesso em: 20 jun 2020.

SARETTA, Cassia B. Compensação de Reserva Legal em Unidade de Conservação: Trajetórias, Fortalezas, Oportunidades e Desafios. 2017. (Mestrado em Desenvolvimento Econômico). Instituto de Economia. Universidade de Campinas, Campinas, 2017.

SASSEN, Saskia. Expulsões: brutalidade e complexidade na economia global. Rio de Janeiro: Paz \& Terra, 2016.

SAUER, Sérgio. Terra no século XXI: Desafios e perspectivas da questão agrária.

Retratos de Assentamentos, Araraquara, v. 19, n. 2, p. 69-97, jul/dez. 2016. 
SAUER, Sérgio; LEITE, Acácio Z.; TUBINO, Nilton L. G. Agenda política da terra no governo Bolsonaro. Revista da Anpege, Dourados, v. 16, n. 29, p. 283-316, 2020.

SAUER, Sérgio e LEITE, Sérgio Pereira. Expansão Agrícola, Preços e Apropriação de Terra Por Estrangeiros no Brasil. Revista de Economia e Sociologia Rural, Piracicaba, v. 50, n. 3, p. 503-524, jul/set. 2012.

SCOLESE, Eduardo. De FHC a Lula: manipulações, números, conceitos e promessas de reforma agrária. Terra Livre, Goiânia, ano 20, v. 2, no 23, p. 123-138, jul/dez. 2004.

SILVA, José G. da. Buraco negro: a reforma agrária na Constituinte de 1987-88. Rio de Janeiro: Paz e Terra, 1989.

SOUZA, José G. de. O imposto territorial rural e os municípios: o impacto nas receitas municipais e a renúncia fiscal. Ciência Rural, Santa Maria, v. 34, n. 5, p. 1563-1569, set/out. 2004.

SPAROVEK, Gerd. A qualidade dos assentamentos da reforma agrária brasileira. São Paulo: Páginas \& Letras Editora e Gráfica, 2003.

STEDILE, João P. (org,). Experiências históricas de reforma agrária no mundo. São Paulo: Expressão Popular, 2020.

SVAMPA, Maristella. "Consenso de los commodities" y lenguajes de valoración en América Latina. Nueva Sociedad, Buenos Aires, n. 244, p. 30-46, mar/abr. 2013. 